\title{
Prevention and surgical treatment of lymphatic injuries in geriatric surgery
}

\author{
F Boccardo , , C Campisi, S Accogli, C Campisi, C Campisi \\ From de Senectute: Age and Health Forum \\ Catanzaro, Italy. 5-7 December 2009
}

\section{Background}

The rate of occurrence of post-operative complications after inguinal lymphadenectomy reported in Literature is of $6-40 \%$ for seromas or lymphocele, $2-4 \%$ for haematomas, $17-65 \%$ for wound dehiscence, $6-20 \%$ for wound infection and $22-80 \%$ for lymphoedema (1-3)

The problem of prevention of lymphatic injuries in geriatric surgery is extremely important if we think about the frequency of both early complications such as lymphorrhea, lymphocele, wound dehiscence and infections and late complications such as lymphangites and lymphedema. Nowadays, it is possible to identify patients at risk and prevent these lesions or treat them at an early stage. This study helps to demonstrate how important it is to integrate diagnostic and clinical findings in order to better understand how to properly identify patients at risk of lymphatic injuries and, therefore, when it is useful and proper to use prevention.

\section{Material and methods}

The authors' experience includes 85 geriatric patients who underwent procedures to prevent and/or treat lymphatic injuries after trauma or surgery. The main causes of secondary lymphatic injuries are represented by surgical operations, irradiations, infections, traumas, metastatic lymphnodal involvement. The high risk surgical operations include: radical mastectomy, WertheimMeigs operation, oncologic operation in urology, abdominal surgery, lymphadenectomies in "critical sites" (groin and axilla). Other operations are represented by exeresis of lipomas in critical sites, saphenectomy, inguino-crural hernioplasty. Authors report their experiences in the prevention and treatment of lymphatic injuries after surgical operations and trauma in geriatrics. After an accurate diagnostic approach (also

Department of Surgery, Unit of Lymphatic Surgery and Microsurgery, San Martino Hospital, University of Genoa, Italy lymphoscintigraphy), prevention is based on different technical procedures among which microsurgical procedures. It is very important to follow-up the patient not only clinically but also by lymphoscintigraphy.

\section{Results}

A protocol of prevention was identified of secondary limb lymphedema that included, from the diagnostic point of view, lymphoscintigraphy and, as concerns therapy, it also recognized the role of early microsurgery. It is necessary to accurately follow-up the patient who has undergone an operation at risk for the appearance of lymphatic complications especially in geriatric age and, even better, to assess clinically and by lymphoscintigraphy the patient before surgical operation.

\section{Conclusions}

Authors' proposal of prevention and early treatment of secondary lymphatic injuries (Figure 1) might, therefore, be applied by all different specialists (general surgeons, urologists, gynaecologists, oncologists, radiotherapists) during their daily clinical activity to try to get to the aim of preventing the patients, especially in geriatrics, who undergo "risk" operations, from also fighting against complex lymphatic acquired disorders such as lymphorrhea, lymphocele, lymphedema, besides their already more or less serious primary pathological condition.

\section{Published: 19 May 2010}

\section{References}

1. Roses DF, Brooks AD, Harris MN, Shapiro RL, Mitnick J: Complications of level I and II axillary dissection in the treatment of carcinoma of the breast. Annals of Surgery 1999, 230(2):194-201.

2. Tonouchi H, Ohmori Y, Kobayashi M, Konishi N, Tanaka K, Mohri Y, Mizutani $H$, Kusunoki M: Operative morbidity associated with groin dissections. Surg Today 2004, 34(z):413-8. 


\begin{tabular}{|c|c|}
\hline \multicolumn{2}{|l|}{$\begin{array}{l}\text { Identification of the risk factors } \\
\text { Identification of the protective factors }\end{array}$} \\
\hline $\begin{array}{l}\text { Patients without anamnestic risk } \\
\text { Education of the patient to autoexamination } \\
\text { Clinical examination }\end{array}$ & $\begin{array}{l}\text { Patients with potential anamnestic risk } \\
\text { Education of the patient to autoexamination } \\
\text { Clinical examination } \\
\text { Lymphoscintigraphy }\end{array}$ \\
\hline \multicolumn{2}{|l|}{$\begin{array}{l}\text { Secondary prevention } \\
\text { Clinical examination } \\
\text { Lymphoscintigraphy }\end{array}$} \\
\hline $\begin{array}{l}\text { Clinical examination negative } \\
\text { Lymphoscintigraphy negative }\end{array}$ & $\begin{array}{l}\text { Clinical examination negative } \\
\text { Lymphoscintigraphy positive }\end{array}$ \\
\hline $\begin{array}{l}\text { Follow up } \\
(6-12 \text { months and } \\
\text { once a year for } 5 \text { years })\end{array}$ & $\begin{array}{l}\text { Personal care } \\
\text { Appropriate behavioural changes } \\
\text { Manual lymphdrainage } \\
\text { Follow up }\end{array}$ \\
\hline \multicolumn{2}{|l|}{$\begin{array}{l}\text { Clinical examination positive } \\
\text { Lymphoscintigraphy positive }\end{array}$} \\
\hline \multicolumn{2}{|c|}{$\begin{array}{l}\text { Manual and mechanical lymphdrainage, bandages } \\
\text { Elastic compression } \\
\text { Early Microsurgery }\end{array}$} \\
\hline
\end{tabular}

Figure 1

3. Boccardo F, Casabona F, De Cian F, Friedman D, Villa G, Bogliolo S, Ferrero S, Murelli F, Campisi C: Lymphedema microsurgical preventive healing approach: a new technique for primary prevention of arm lymphedema after mastectomy. Ann Surg Oncol 2009, 16(3):703-8.

doi:10.1186/1471-2318-10-S1-A42

Cite this article as: Boccardo et al:: Prevention and surgical treatment of lymphatic injuries in geriatric surgery. BMC Geriatrics 2010 10(Suppl 1):A42.

\section{Submit your next manuscript to BioMed Central} and take full advantage of:

- Convenient online submission

- Thorough peer review

- No space constraints or color figure charges

- Immediate publication on acceptance

- Inclusion in PubMed, CAS, Scopus and Google Scholar

- Research which is freely available for redistribution

Submit your manuscript at www.biomedcentral.com/submit 